\title{
Die toekoms van die sosiale wetenskappe in die nuwe Suid-Afrika
}

\author{
Anna F. Steyn \\ Departement Sosiologie \\ Randse Afrikaanse Universiteit \\ JOHANNESBURG
}

\begin{abstract}
The development of the social sciences has been closely linked to increasing cultural contact and the emergence of social problems in society. The question of the applicability of the body of knowledge in the social sciences for the improvement of conditions in society was raised particularly after the Industrial Revolution when social conditions began to change drastically and social problems increasingly made their appearance. This alignment with applicability finally resulted in the development of the socalled helping professions and the acceptance in formal organisations of the status of professional social scientists.

The relevance of the social sciences will increase in the New South Africa. This statement is based on the fact that a successful future political dispensation will not automatically mean that all social problemis will immediately disappear. In fact, the prognosis - based on trends in the past as well as the present is that there will be an escalation of social problems such as urbanization and the growth of squatter camps, breakdown of schools and the disintegration of the fanily. Social scientists will have to play an important role in handling these problems. It would therefore be extremely shortsighted if universities should fail to provide a thorough training for social scientists.
\end{abstract}

\section{Inleiding: historiese agtergrond}

'n Antwoord op die vraag na die rol van die sosiale wetenskappe in die samelewing - nou en in die toekoms - is reeds tot 'n mate te vinde in die samelewingstoestande waaronder dit ontwikkel het. 'n Kort historiese terugblik op die ontwikkelingsgeskiedenis van die sosiale wetenskappe kan dus belangrike insigte in dié verband na vore bring.

Hoewel daar waarskynlik al in prehistoriese tye uitsprake oor die aard van sosiale verhoudings en strukture in gemeenskappe gemaak is, was dit eers toe meer 
Die toekoms van die sosiale wetenskappe

komplekse samelewings kontak met mekaar begin maak het, dat daar 'n begin gemaak is om sosiale verskynsels met 'n mate van objektiwiteit te bejeën, en beskrywings en verduidelikings te gee van sosiale aangeleenthede soos hulle werklik voorkom.

Van die vroegste sosiale teorieë het by die ou Griekse wysgere ontwikkel en het deur die eeue afwisselend gedurende bepaalde periodes minder aandag gekry en verval en dan weer vir periodes vinniger ontwikkel en gebloei. Dit is besonder interessant om daarop te let dat die periodes van afname in sosiale denke gedurende die periodes van meer geïsoleerde bestaan van gemeenskappe voorgekom het, terwyl kultuurkontak soos byvoorbeeld deur die Kruistogte en later gedurende die Renaissance ' $n$ opbloe: in sosiale denke teweeggebring het.

Opvallend aangaande die sosiale denke gedurende hierdie vroeë ontwikkelingsfases is die feit dat die samelewing in totaliteit ontleed is. So het 'n denker in sy ontleding van die samelewing onder andere die politieke, die ekonomiese en die godsdienstige aspekte, die gesinslewe, die plek van die vrou en nog veel meer in aanmerking geneem, en was die kennisveld van die sosiale denke in 'n groot mate 'n ongedifferensieerde geheel (Becker \& Barnes, 1961: 506).

'n Besondere kenmerk van die vroeëre sosiale denke - veral gedurende die Middeleeue tydens die oorheersing van die Roomse-Katolieke kerk - was die feit dat van die standpunt uitgegaan is dat sosiale instellings en orde Godgegewe is en dat die mens weinig daaraan kan verander (Becker \& Barnes, 1961: 236).

Dit is eers sedert die Renaissance en gedurende die laat 17 de en 18 de eeu toe suksesvolle seereise gelei het tot die ontdekking van ander wêrelddele en kultuurkontak verskerp het dat daar 'n sterk opbloei in die sosiale denke na vore getree het (Becker \& Barnes, 1961: 460; Rossides, 1978: 28-31). Hierdie tendens ontwikkel in samehang met die groei van die natuurwetenskappe.

Wat die natuurwetenskappe betref, het daar ' $n$ hele nuwe benadering tot die verkryging, die aard en geldigheid van kennis ontwikkel. Hierdie benaderingswyse het gelei tot die ontwikkeling van die navorsingsmetodes van die moderne natuurwetenskappe wat op waarneming, meting, vergelyking en matematiese formulering berus. Hoewel hierdie denkstrominge nie inhoudelik direk op die ontwikkeling van die sosiale denke as sodanig betrekking gehad het nie, was hulle tog in die algemeen van die uiterste belang in die ontwikkeling van die sosiale wetenskappe. Daar is geredeneer dat indien dieselfde studiemetodes wat die omvangryke resultate in die fisiese wetenskappe gegee het, in die studie van samelewingsverskynsels toegepas sou word, daar tot werklike kennis van die samelewing en aard daarvan gekom sou kon word. 


\section{Die idee van vooruitgang en verbetering van die samelewing}

Saam met die ontwikkeling van die natuurwetenskappe en die besef dat die resultate daarvan ter verbetering van die lewensomstandighede van die mens aangewend kan word, tree die idee van vooruitgang op samelewingsgebied ook na vore. Hierdie idee van vooruitgang was 'n redelik sentrale tema van die sosiale wetenskappe in die 19de eeu, waar die hoofbelangstelling geleë was in die ontdekking van die aard van vooruitgang en die vasstelling van die middele ter realisering daarvan.

Gedurende hierdie tyd begin die belangstelling in die sosiale wetenskappe met die oog op verbetering van die lewensomstandighede van die mens so 'n wye omvang aanneem, dat afsonderlike vakwetenskappe geleidelik begin uitkristalliseer - in toedrag van sake wat verder gestimuleer is deur bepaalde ontwikkelings en veranderings wat die samelewing van die $19 \mathrm{de}$ eeu self ondergaan het, naamlik die Industriële Rewolusie en hernude stedelike groei.

Hierdie rewolusie het nie sonder pyn en menslike lyding verloop nie. So het die fabrieke wat deur die Industriële Rewolusie tot stand gekom het, arbeid verskaf aan groot getalle mense wat in die stede begin saamdrom het. Aanvanklik was hierdie arbeidersklas mateloos uitgebuit deur lae lone, lang werksure, vroue- en kinderarbeid. Afgesien daarvan was behuising en sanitasie swak en het hierdie wantoestande tot baie emstige sosiale vraagstukke aanleiding gegee (Smelser, 1959:184-193)

Op grond van hierdie wantoestande word daar vir die eerste keer in die sosiale denke daadwerklike pogings aangewend om deur wetenskapsbeoefening hierdie wantoestande die hoof te bied. In dié verband kom daar hoofsaaklik twee breë denkstrominge na vore. Aan die een kant ontwikkel die werk van Karl Marx, waarin aangetoon word dat die samelewing breedweg in die besitters- en die arbeidersklas polariseer en dat die besittersklas die arbeidersklas mateloos uitbuit. Die oplossing vir dié probleem sien hy in die ontwikkeling van die rewolusie waar die omverwerping van die heersersklas tot 'n meer regverdige samelewing sal lei.

Aan die ander kant ontwikkel daar die meer struktureel-funksionele benadering. In hierdie benadering word daar gewerk aan sosiale heropbouplanne en skemas waardeur die armoede en ellende bekamp word. Hierdie skemas was aanvanklik hoofsaaklik op meegevoel gebaseer, maar mettertyd het die denkers van die tyd tot die besef gekom dat indien die hervonningsgedagte enigsins van betekenis moet wees, dit op positiewe feitekennis gebaseer moet wees, naanlik die wetenskap van die samelewing, soos hulle dit dan ook gestel het. Hierdie insigte het gelyktydig in verskillende samelewings soos in die VSA, Engeland, Frankryk 
en Duitsland ontwikkel. So het die Fransman Comte, wat as die vader van die sosiologie gesien word, dan ook eksplisiet van die nuwe wetenskap, die sosiologie, gepraat as die nuwe godsdiens op grond waarvan die samelewing geherkonstrueer moet word (Collins, 1981:74).

$\mathrm{Na}$ Comte het daar ' $\mathrm{n}$ tydlank ' $\mathrm{n}$ polemiek bestaan of dit wel moontlik is om verbetering in die samelewing deur middel van die sosiale wetenskappe aan te bring. Spencer was in dié verband van mening dat ingryping van samelewingskant die natuurlike ewolusieproses aan bande sal lê en dat die sosiale wetenskap dus nie vir hierdie doeleindes aangewend moet word nie (Timasheff, 1967:41). Daarenteen was ' $n$ man soos Lester $F$. Ward van mening dat die sosiale wetenskappe wel as ' $n$ instrument in die hantering van maatskaplike probleme aangewend kan word. Vir hom was veral die opvoeding van besondere groot belang in die hantering van maatskaplike probleme. Verder stel hy dit eksplisiet dat die mens deur sy ontledingsvermoë en deur sy vermoë om toekomstige doelstellings wat deur aktiewe handeling nagestreef word, daar te stel, daartoe kan bydra om samelewingsomstandighede te verbeter (Timasheff, 1967: 75).

Die idee dat samelewingsomstandighede en wantoestande deur die toepassing van wetenskapskennis verbeter kan word, het geleidelik veld begin wen en dit het as 'n belangrike stimulus vir ' $n$ toename in sosiale navorsing en 'n versnelde ontwikkeling van die sosiale wetenskappe gedien

\section{Die Industriële Revolusie, samelewingsproblematiek en -heropbou}

'n Belangrike insig is reeds vroeg deur navorsing blootgelê: die tegnologie en die Industriële Rewolusie het nie net tot die aanvanklike uitbuiting van mense en die ontwikkeling van wantoestande aanleiding gegee nie, maar dit het ' $n$ totale maatskaplike rewolusie teweeggebring - 'n rewolusie wat die sosiale struktuur van die samelewing in totaliteit verander het. Hierdie verandering in die maatskaplike struktuur was noodsaaklik om die tegnologie suksesvol in die produksieproses te kon implementeer. Die ou tradisionele maatskaplike strukture het naamlik nie meer voorsien in die eise gestel deur die nuwe produksiewyses en kommersiële sisteem nie en ook nie in die eise op die gebied van bestuur en beheer nie. Die ou strukture het dus toenemend begin verval en nuwe strukture het begin ontwikkel om in hierdie nuwe eise te voorsien. Tog het die oorgang van die ou strukture na die nuwe strukture nie probleemloos verloop nie, aangesien die nuwe strukture nie altyd so goed as die ou tradisioneles in sekere basiese behoeftes van die mens self kon voorsien nie. Die gevolg was dat 'n groot mate van spanning en disorganisasie ontwikkel het - aspekte wat tot ' $n$ toename in individuele en maatskaplike probleme gelei het (Ogburn, 1957) 
Ter illustrasie van hierdie eskalerende probleme kan na enkele voorbeelde in die Suid-Afrikaanse samelewing verwys word.

Een van die individuele probleme wat hier te lande ' $n$ baie groot omvang aanneem is dié van alkoholisme en dwelmverslawing. Senekal en Joubert (1988: 16) wys in dié verband daarop dat die beraamde koste vir alkoholisme as gevolg van verlaagde produksie in 1985 reeds tot R1 178 miljoen ge-eskaleer het. Dit word ook verder bereken dat tot $6 \%$ volwasse blanke mans bo 15 jaar en $22 \%$ kleurling mans bo 20 jaar, 'n drankprobleem mag hê. As verder in aanmerking geneem word dat een persoon met 'n alkoholprobleem die lewens van tot 16 persone in sy onmiddellike omgewing affekteer, kan die ontwrigting wat hierdie probleem teweegbring 'n baie groot omvang hê.

'n Samelewingsprobleem wat ook toenemend na vore kom en talle persone se lewens ontwrig, is dié van gesinsdisorganisasie en egskeiding. Die moderne samelewing stel besonder hoë eise aan die kerngesin en maak van die gesin ' $n$ baie kwesbare instelling. Hoe kwesbaar die gesin geword het, blyk baie duidelik uit die toename in egskeidingsyfers wat van $1,9 \%$ per duisend bestaande huwelike in 1918 na tot so hoog as $16,5 \%$ in die 1980 jare gestyg het. In onverwerkte getalle beteken dit dat in die dekade 1978-1987 altesaam 164483 huwelike in die egskeidingshof beland het, waarby 206738 aflanklike kinders betrokke was. Hierdie toename in egskeidings is maar een van die probleme waarvoor die gesin te staan kom (Steyn, et al.,1989: 125).

Daar is ook 'n toename in die persentasie buite-egtelike geboortes en 'n onrusbarende toename in gesinsgeweld en kindermishandeling waardeur onnoembare skade aan kinders gedoen kan word. Hierdie probleme in die gesinslewe kan mettertyd 'n skadelike invloed op die landsekonomie begin uitoefen. Clem Sunter (1987:32) beklemtoon byvoorbeeld dat kinders, slegs in samelewings waar hulle in 'n gesonde huislike atmosfeer opgroei, die regte werksetiek kan ontwikkel werksetiek wat essensiël is vir die handhawing en ontwikkeling van ' $n$ gesonde ekonomie.

Hoewel die tegnologie dus bepaalde vorme van veral ekonomiese vooruitgang gebring het, het dit duidelik begin word dat dit met so 'n mate van samelewingsproblematiek gepaard gegaan het, dat die volle potensiaal daarvan nie verwesenlik sou kon word sonder die suksesvolle hantering van die samelewingsproblematiek nie. 


\section{Die sosiale wetenskappe en die hantering van die samelewingsproblematiek}

Vir die hantering van die individuele en samelewingsprobleme het die insette en kennis gegenereer deur die sosiale wetenskappe onontbeerlik begin word en het die ondersteunende professies begin ontwikkel. Kundiges soos die kliniese sielkundige, die voorligtingsielkundige, die maatskaplike werker, ensovoorts, word primêr in die sosiale wetenskappe opgelei en lewer diens in die ondersteunende professies. Hierdie ontwikkeling van die ondersteunende professies het gedien as verdere stimulus vir toenemende navorsing en onderrig in die sosiale wetenskappe op universiteitsvlak. In Suid-Afrika byvoorbeeld is die instelling van Sosiologie en Maatskaplike werk aan universiteite 'n direkte uitvloeisel van 'n aanbeveling van die Camegie Kommissie in 1932 (Grosskopf, 1932: xxxii) met die oog op die hantering van die armblankevraagstuk.

Die werk wat deur die ondersteunende professies gedoen word, is egter nie die enigste wyse waarop die sosiale wetenskappe 'n relevante rol in die moderne samelewing speel nie. Die besonder ingewikkelde aard wat die menslike verhoudings in groot ondernemings, die formele organisasies soos hospitale, kerke, skole, die leër, die polisie ensovoorts aangeneem het, die ingewikkelde aard van etniese verhoudings in plurale samelewings, intenasionale verhoudings en die versekering van nasionale veiligheid binne landsgrense het sosiaal-wetenskaplike navorsing en kennisinsette op hierdie gebiede genoodsaak. Daar word dan ook toenemend gebruik gemaak van opgeleide sosiaal-wetenskaplikes soos personeelbeamptes, sosioloë, bedryfsosioloë, sielkundiges, bedryfsielkundiges, antropoloë en politieke wetenskaplikes vir die hantering van die menslike verhoudings op hierdie gebiede met die oog op die maksimalisering van uitsette.

Opgeleide sosiaal-wetenskaplikes kan byvoorbeeld 'n bydrae lewer

* deur ' $n$ aandeel te neem in die beleidsformulering,

* deur die nodige navorsingsdata-insette te verskaf op grond waarvan beleid geformuleer kan word,

* deur die nodige insette in menslike verhoudingsverband vir die suksesvolle implementering van die beleid te lewer,

* deur die toepassing van relevante sosiaal-wetenskaplike kennis in die situasie waar hulle werksaam is (Lazarsfeld et al., 1967; MacRae, 1976).

In hierdie verband is dit interessant om daarop te let dat die toepassing van sosiaal-wetenskaplike kennis in bepaalde beroepsituasies nie noodwendig deur professionele sosiaal-wetenskaplikes gedoen word nie. Daar is vele beroepe met 'n spesifieke beroepsopleiding soos byvoorbeeld dié van die mediese dokter, die 
verpleegster, die onderwyser, die predikant, waar sosiaal-wetenskaplike kennis 'n belangrike agtergrond vir werkverrigting verskaf. Hierdie kemnisinsette gee aan byvoorbeeld die mediese dokter, die verpleegster, die onderwyser of die predikant die vermoë on ook die menslike verhoudingsaspekte in die spesifieke beroep waarvoor hy opgelei is en waarin hy staan met sukses te kan hanteer

In die toepassing van die sosiaal-wetenskaplike kennis was daar aanvanklik, en is daar tans nog, tot 'n groot mate 'n sterk neiging om 'n bepaalde probleem vanuit ' $n$ invalshoek van 'n bepaalde sosiale wetenskap te benader. Hierdie probleembenadering neem die bepaalde veranderlikes wat sentraal aan die bepaalde wetenskap staan, in aanmerking. Die mens se gedrag word egter nie op een tydstip slegs beïnvloed deur die veranderlikes soos deur 'n bepaalde wetenskap bestudeer nie, maar alle veranderlikes speel op 'n geïntegreerde wyse 'n rol in sy gedrag. Deur menslike gedrag net vanuit een invalshoek te bestudeer, word dus 'n oorvereenvoudigde en onvolledige beeld van die situasie en 'n mens se gedrag in die situasie gegee. 'n Belangrike ontwikkeling wat dus in die ontleding van sosiale verskynsels begin plaasvind het, is dat daar 'n neiging tot toenemende konvergensie en integrasie van die kennis van die verskillende sosiale wetenskappe na vore begin tree het. So is daar al meer en meer 'n neiging om 'n bepaalde sosiale verskynsel op 'n interdissiplinêre wyse te bestudeer, met die oog op die daarstelling van die mees volledige beeld van die bepaalde verskynsel. Hierdie interdissiplinêre benadering het toenemend na vore getree ten opsigte van probleemvelde in die moderne samelewing, soos byvoorbeeld die problematiek van die groot stad en stadsbeplanning, die ontwikkeling van onderontwikkelde volkere, die problematiek van gesinsdisintegrasie, die benadering daarvan, en nog vele meer (Steyn, 1979: 6).

As samevattend na die rol van die sosiale wetenskappe gekyk word in die hantering van samelewingsproblematiek in die moderne samelewing en die rol wat dit tans in die gladde funksionering van sosiale verhoudings speel, is dit duidelik dat die sosiale wetenskappe onontbeerlik in die samelewing geword het en reeds 'n vaste plek daarin begin inneem het. Belangrike vrae wat egter in dié verband na vore kom is: wat van die rol van die sosiale wetenskappe in die nuwe en toekomstige Suid-Afrika? Gaan dic sosiale wetenskappe hier hoegenaamd 'n rol hê, en indien wel, wat?

\section{Samelewingsproblematiek in die nuwe Suid-Afrika}

Suid-Afrika is 'n land wat op hierdie tydstip in 'n staat van omvattende vloeibaarheid en politieke verandering verkeer. Terwyl daar gepoog word om onderlaandelings tussen die verskillende bevolkings- en belangegroepe te laat vlot, vind 'n groot mate van politieke maneuvrering plaas, is daar spontane uitbarstings van kollektiewe gedrag en toeneınende beplande massa-aksie, verhard sommige van 
die politieke partye se houdings ten opsigte van mekaar en word opponerende uitgangspunte in die politiek dikwels meer en sterker geartikuleer.

Hierdie vloeibare toestand van verandering is nie net tot die politieke arena beperk nie, maar dit word in al die ander sektore van die samelewing waargeneem - in die ekonomie, die godsdienstige lewe, in die onderwys, in die regsisteem, in die gesinslewe en in stedelike ontwikkeling, om maar enkeles te noem.

Te midde van al hierdie onrus en gewoel werk die regering konsekwent in die rigting van onderhandelings met die verskillende belanghebbende partye, ten einde eventueel ' $n$ vreedsame skikking te bereik waardeur gelyke geleenthede vir almal daargestel sal word, sodat elke persoon in die samelewing in staat gestel sal word om sy volle potensiaal te verwesenlik. Presies wat die afloop van hierdie onderhandeling gaan wees is op hierdie tydstip nog nie duidelik nie, maar wat die vorm van die regering of wie die leiers ook al mag wees, een aspek waaroor daar geen onduidelikheid kan wees nie, is dat die nuwe regering voor sekere realiteite in die Suid-Afrikaanse samelewing te staan gaan kom wat nie outomaties met die bereiking van ' $n$ politieke skikking sal verdwyn nie. Sekere probleme wat die dringende aandag van die regering sal eis en waarvoor oplossings gesoek sal moet word, sal steeds bly voortbestaan.

\subsection{Die probleem van swart verstedeliking}

Een van die mees uitdagende probleme waarvoor die nuwe Suid-Afrika te staan gaan kom is die van die snelle verstedeliking van die swart man (Steyn, 1991:55). Die swart man in die RSA is die bevolkingsgroep wat persentasiegewys die minste verstedelik is. Hierdie verskynsel is deels te wyte aan die feit dat die swartes aanvanklik deur die beleid van apartheid ontmoedig is om permanent in stedelike areas te vestig. Die stedelike lewe is bloot as 'n tydelike fase vir die swartes gesien, en dié wat in die stad, veral in die wit metropolitaanse areas gewoon het, is aangemoedig om na die sogenaamde landelike tuislande terug te beweeg. Grens-industrieë is ontwikkel om addisionele indiensneming in die tuislande te voorsien, en stedelike ontwikkeling is binne die tuislande aangemoedig. Wat indiensneming in die wit metropolitaanse gebiede betref, is voorkeur aan volwasse manlikes gegee en hulle is aangennoedig om hulle gesinne in die landelike gebiede agter te laat, en tussen die landelike gebiede en die stad te pendel - ' $n$ toedrag van sake wat aanleiding gegee het tot die ontwikkeling van 'n omvattende sisteem van trekarbeid wat die gesinslewe van die swartes baie nadelig beïnvloed het.

Hierdie beleid ten opsigte van die vestiging van die swartes in die landelike areas het aanleiding gegee tot ' $n$ uitermate hoë bevolkingsgroei in tuislande - ' $n$ verskynsel wat die ekonomiese situasie van die swartes in die tuislande baie nadelig beinvloed (kyk Giliomee \& Schlemmer, 1985:196). In 'n oorsigtelike ontleding 
van die tuislande is dit duidelik dat daar wel groei in die bruto binnelandse produk sowel as die bruto nasionale inkomste is. Die groei in die bruto binnelandse produk toon aan dat die ontwikkelingspogings van die Suid-Afrikaanse regering nie geheel en al onsuksesvol was nie, terwyl die groei in die bruto nasionale inkomste van die moderne sektor ' $n$ resultaat is van stygende lone wat deur die toenemende aantal immigrante verdien word (Giliomee \& Schlemmer, 1985: 197198).

Werkgeleenthede in die tuislande begin egter toenemend skaars word. Alhoewel die aantal klein ondernemings onder die swartes aan die vermeerder is - 'n tendens wat toon dat 'n gees van entrepeneurskap nie by hulle ontbreek nie - is daar veral ' $n$ gebrek aan dinamiese ontwikkeling in die landbousektor. Die feit dat die landbousektor in die tuislande nie voldoende ontwikkel nie, veroorsaak dat armoede toeneem onder diegene wat in dié gebiede woon.

Een van die belangrikse faktore wat tot hierdie armoede bydra, is die ontoereikende voorsiening van grond om aan die landboubehoeftes van die swart landelike bevolking te voldoen. ' $n$ Bydraende faktor is die feit dat al die beskikbare grond nie bewerk word nie, en waar landbougrond bewerk word, word nie voldoende daarin geslaag om boerderymetodes op te gradeer en sodoende tred te hou met die veranderende grond-bevolkingsverhouding nie. Dit lei onder andere tot gronduitputting en tot die feit dat landbouproduksie nie voldoende is om in die behoeftes van die bevolking te voorsien nie. Grootskaalse armoede is aan die orde van die dag en saam met oorbevolking lei dit daartoe dat daar toenemend druk tot verstedeliking by die swart man is - 'n proses wat tans, nadat die wette op instromingsbelheer afgeskaf is, teen 'n versnellende tempo plaasvind.

In die lig van die bevolkingsamestelling waarin die swartes die grootste deel van die Suid-Afrikaanse bevolking vorm, naamlik $69,9 \%$, maar verreweg die bevolkingsgroep is wat die minste verstedelik is, naamlik slegs $39,6 \%$ (in 1985), en die feit dat die bevolkingsgroeikoers by swartes die hoogste van al die groepe is, is dit duidelik dat die grootste druk om te verstedelik van hierdie verarmde swart bevolkingsgroep sal kom (Steyn, 1991:52).

Die huidige proses van verstedeliking onder die swart bevolking verskil as gevolg van die druk tot verstedeliking, in 'n baie groot mate van die proses van verstedeliking gedurende die vroeëre deel van hierdie eeu na die ontdekking van goud en diamante en veral gedurende die proses van sekondêre industrialisering na Wêreldoorlog II tot voor 1970. Hierdie eerste fase van verstedeliking in SuidAfrika was tipies van die proses van verstedeliking wat in alle industriële lande in die wêreld plaasgevind het. Gedurende hierdie eerste fase het die verbeterde tegnologie in die landbou tot 'n agrariese rewolusie gelei waardeur daar enersyds voedselsurplusse vir 'n toenemende stedelike bevolking geproduseer is, en andersyds is mense vry gemaak van landbou-arbeid met 'n gevolglike surplusbevolking 
Die toekoms van die sosiale wetenskappe

in die landelike areas wat deur die ontwikkelende mynindustrieë en later ontwikkelende sekondêre industrieë geabsorbeer is

Hoewel hierdie proses van verstedeliking aanvanklik hand aan hand gegaan het met ' $n$ mate van sosiale disorganisasie, het daar op die lang duur 'n redelik stabiele stedelike lewe ontwikkel met 'n soliede middel- en werkende klas waar mense, in die geheel gesien, op 'n gesonde wyse in hul daaglikse lewensbehoeftes kon voorsien. Ongelukkig het die sisteem van instromingsbeheer en trekarbeid die natuurlike vloei van verstedeliking onder die swartes verhinder, en dit het, soos reeds aangedui, tot 'n groot mate van armoede, werkloosheid en oorbevolking in die landelike areas gelei met 'n gevolglike toenemende druk vir verstedeliking

Selfs voor die verwerping van die wette op instromingsbeheer het 'n klein maar konstante stroom van swartes na die stede - weliswaar onwettig - gemigreer om daar ' $n$ bestaan te maak. Na die afskaffing van hierdie wette op instromingsbeheer het hierdie stroom migrante na die stede vertienvoudig.

Hierdie drastiese proses van verstedeliking onder die swartes volg die tipiese patroon kenmerkend van derdewêreld-verstedeliking: die landbou in hierdie lande is nie eens in so ' $n$ mate ontwikkel en gemoderniseer dat dit in voedselsurplusse vir 'n groeiende bevolking kan voorsien nie, en met 'n hoë geboortekoers en 'n vinnige groeiende bevolking kan dit skaars in die behoeftes van die landelike bevolking voorsien. Hierdie toedrag van sake lei tot die ontwikkeling van 'n surplusbevolking sonder ' $n$ bestaanswyse in die landelike gebiede, sodat hulle eventueel na die stede begin migreer. In die stede is dit ook nie altyd moontlik om in die indiensnemingbehoeftes van die vinnig groeiende bevolking te voorsien nie, omdat 'n gebrek aan sommige van die mees belangrike produksiefaktore, naamlik akkumulatiewe kapitaal, entrepeneurskap, tegniese kennis en geskoolde mannekrag ondervind word.

Die versnellende verstedeliking onder die swartes is besig om tot die ontstaan van 'n groot aantal probleme te lei. Nie net is daar 'n onvermoë by die regering, die plaaslike outoriteite, en die mense self om in die nodige behuising en dienste soos sanitasie, water, elektrisiteit of vullisverwydering te voorsien nie, maar dit is ook twyfelagtig of die groei in die ekonomiese sektor - die industriële, die kommersiële en dienste-sektore - vinnig genoeg is om die nodige voorsiening vir indiensneming te maak. Afgesien van die voorsiening in hierdie basiese behoeftes van die mense, is dit nog moeiliker om in hoërvlakdienste soos die voorsiening van skole, hospitale en ander nodige fasiliteite te voorsien. Hierdie toedrag van sake gee daartoe aanleiding dat daar 'n toename in die verskynsel van plakkery of sogenaamde informele nedersettings voorkom. In 1981 het Smith en Booysen byvoorbeeld die plakkers op 1,5 miljoen geskat terwyl die Stedelike Stigting in 1988 hierdie plakkersbevolking op ongeveer 7 miljoen mense geskat het. 
Indien die totale opset van hierdie informele nedersettings in aanmerking geneem word, is dit voor die handliggend dat armoede, werkloosheid, swak behuising en sanitasie, en die gebrek aan gesondheids-, opvoedkundige en ander fasiliteite, tot die eskalering van probleme soos jeugmisdaadbendes, misdaad en geweld kan lei.

Die situasie soos geskets, is een van die belangrike sosiale realiteite waarvoor die nuwe regering te staan sal kom en wat hulle na die beste van hul vernoë sal moet hanteer en probeer oplos - en die vooruitsig dat hierdie probleme in die nabye toekoms maklik opgelos sal word, is twyfelagtig. Indien gekyk word na die vooruitskattings van die toename in die stedelike swart bevolking in vergelyking met dié van die ander bevolkingsgroepe, is dit duidelik dat daar vir nog 'n aantal dekades eerder ' $n$ toename as ' $n$ afname in hierdie probleme sal wees. Die volgende syfers is 'n vooruitskatting van die stedelike bevolkingsgroei wat goedgunstiglik deur die Stedelike Stigting verskaf is.

Tabel 1: Vooruitskatting van stedelike bevolkingsgroei vir alle bevolkingsgroepe RSA 1990-2010

\begin{tabular}{|l|l|l|l|l|}
\hline & Blank & Kleurling & Asiërs & Swart \\
\hline 1990 & 3,582100 & 1,941300 & 830200 & 11,027600 \\
\hline 1995 & 3,777800 & 2,165900 & 904800 & 13,609700 \\
\hline 2000 & 3,957700 & 2,382500 & 974000 & 16,805500 \\
\hline 2005 & 4,119800 & 2,586300 & 1,030000 & 19,407000 \\
\hline 2010 & 4,287300 & 2,805700 & 1,088300 & 23,644600 \\
\hline
\end{tabular}

Uit hierdie tabel blyk dit duidelik dat die toename in stedelike bevolking wat as ' $n$ uitdaging gesien kan word, veral onder die swart bevolkingsgroepe voorkom. Daar is op dié stadium reeds 'n geskatte 7 miljoen plakkers onder die swart bevolking en saam met hierdie 7 miljoen plakkers moet daar nog vir ongeveer ' $n$ verdere 13 miljoen nuwe intrekkers na die stad voorsiening gemaak word. Voorsiening hier behels voorsiening van dienste en fasiliteite op alle vlakke: behuising, sanitasie, water, elektrisiteit, paaie, werkverskaffing, skole, munisipale bestuur, godsdienstige fasiliteite en watter instellings daar ook al mag wees. Die groot uitdaging hier is dus eintlik dat al hierdie nuwe intrekkers mettertyd in volwaardige gemeenskappe moet ontwikkel - gemeenskappe met 'n volwaardige gemeenskaplewe en 'n hoë lewenskwaliteit vir al die inwoners.

Op hierdie stadium van ontwikkeling in die reeds gevestigde swart stedelike gebiede is daar steeds ernstige probleemareas. In hierdie verband word daar 
onder andere aan die volgende aspekte gedink: onvoldoende fasiliteite vir die versorging van voorskoolse kinders van gesinne waar albei ouers werk, alle kinders het nie of gebruik nie die geleenthede om opvoedkundige instellings ten volle te benut nie; die stedelike administrasie funksioneer nie altyd effektief in die verskaffing van dienste nie; daar is nie voldoende welsyns- en mediese dienste nie; daar is 'n groot mate van werkloosheid; die swart man is nie altyd ingeskakel by die formele ekonomie nie, veral waar 'n groot persentasie van hulle laer besoldigde posisies beklee. Waar daar dikwels ook 'n baie lae vlak van gemeenskapsbetrokkenheid is, is die inskakeling by hierdie strukture in die informele woongebiede of die sogenaamde plakkersgebiede nog veel meer problematies van aard, aangesien die strukture in die meeste gevalle nie bestaan nie - 'n toedrag van sake wat werklik 'n uitdaging vir die nuwe Suid-Afrika bied.

Saam met en binne die konteks van verstedeliking is sommige van die verdere sosiale realiteite waarvoor ' $n$ toekomstige regering te staan gaan kom, die hantering en ontwikkeling van die bepaalde instellings en die daarmee gepaardgaande fasiliteite waarvan sommige reeds op hierdie stadium 'n groot agterstand beleef. In hierdie verband kan nog twee instellings genoem word wat indringende aandag sal moet kry, naamlik dié vall die onderwys en dié van die gesinslewe. Die ontwikkeling van albei hierdie instellings is van die grootste belang vir die uitbouing van 'n gesonde ekonomie en gesonde gemeenskapslewe.

\subsection{Enkele probleme in swart onderwys}

Wat die onderwys betref, bestaan daar 'n groot diskrepans tussen die onderwysfasiliteite vir wit en swart, en is daar ' $n$ groot agterstand ten opsigte van fasiliteite wat vir die swartes beskikbaar gestel is. Daar is 'n baie groot gebrek aan klaskamerruintes, die onderwyser-kindverhouding is swakker as by enige van die ander bevolkingsgroepe en ook die onderwyskwalifikasies van die swart onderwysers is baie swakker as dié van ander bevolkingsgroepe (Steyn, 1991: 57). Afgesien van die swak fasiliteite is daar ook 'n baie hoë uitvalsyfer onder die skoolkinders en maak slegs 'n geringe persentasie van 'n bepaalde groep skoolbeginners uiteindelik matriek. Hierdie persentasie het weliswaar gedurende die laaste aantal dekades verbeter, maar in vergelyking met dié van die ander bevolkingsgroepe is die persone wat vir matriek inskryf en matriek slaag relatief swak by die swartes (kyk bylae $A, B$ en $C$ ).

Hierdie toedrag van sake word ook verder aansienlik versleg deur disorganisasie in die gesinslewe, die politisering van die jeug en die voortdurende skoolboikotte waardeur heelwat kinders sonder voldoende onderwys die lewe ingestuur word. Daar kan in der waarheid hier van 'n verlore jeug gepraat word omdat hul nie die nodige onderrig ontvang het om tot die beroepslewe toe te tree nie. Om hierdie jeug weer by die hoofstroom van die volwasse beroepslewe ingeskakel te kry om 
Anna F. Sleyn

met 'n normale lewe aan te gaan, sal groot uitdagings aan die toekomstige SuidAfrika stel (Everatt, 1992: 52-68).

\subsection{Gesinsprobleme}

Afgesien van die skool is die gesin ook een van die strukture wat in die vinnig verstedelikte gebiede voor omvattende uitdagings te staan gekom het. Met die proses van verstedeliking het daar 'n groot mate van gesinsverval ontwikkel, en is die ouer-kindverhouding negatief beinvloed. Hierdie negatiewe ouer-kindverhouding lei tot beheerverlies oor kinders, veral waar albei ouers werk, en kinders gevolglik sonder toesig gelaat of in die sorg van ou mense is wat nie die vermoë het om die nodige beheer uit te oefen nie.

Afgesien van dié verandering wat tot verlies aan belıeer binne die gesinskonteks gelei het, het ander belangrike primêre groepe soos die stamskole en die ouderdomsindeling waarin streng beheermaatreëls van primêre aard opgesluit was (en dus tot die handhawing van orde bygedra het) ook met hierdie omwenteling verval en die verlies aan beheer laat eskaleer.

Een van die areas waarin hierdie normatiewe verval besonder opvallend is, is die van die verbrokkeling van die seksuele gedragskodes. So word voorhuwelikse onthouding soos in die tradisionele lewe, nie meer as geldig aanvaar nie, maar word seksuele omgang reeds op vroeë leeftyd uitgetoets, vind kohabitasie maklik plaas, met gevolglike onstabiele verhoudings. Mans wat in hierdie buite-egtelike verhoudings betrokke is, aanvaar selde die verantwoordelikheid vir die buiteegtelike kinders, en verdwyn dikwels van die toneel. Die moeder, wat in baie gevalle 'n heenkome in haar eie gesin van oriëntasie vind, moet die kind of kinders alleen grootmaak.

Hoewel daar nie statistieke oor die buite-egtelike geboortes in die swart stedelike gebiede bestaan nie, blyk die hoë voorkoms van buite-egtelikheid duidelik uit spesifieke gesinstrukture wat na vore kom in 'n onlangse opname wat onder 1,300 swart gesimne in stedelike gebiede gemaak is. Hierdie gesinstrukture is naamlik die vrou-kind-enkelouergesin en die matrifokale multi-generasie-gesinstruktuur wat altesaam $26,6 \%$ van die gesinstrukture onder die swartes verteenwoordig.

As in aanmerking geneem word dat kinders wat in hierdie gesinstrukture opgroei, dikwels buite-egtelik is en merendeels met min toesig in armoedstoestande groot word, is dit voor die hand liggend dat hulle min kanse op sukses het - 'n gegewe wat eventueel tot eskalering van probleme in die stad kan bydra. Waar die wyer verwantskapsgroepering en die uitgebreide gesin in die tradisionele samelewing 'n belangrike rol in die daarstelling en handhawing van georganiseerde gemeenskapslewe gespeel het, impliseer die verval van hierdie strukture in die stad in 'n groot mate die verval en selfs verdwyning van gevestigde gemeenskapslewe. 
Waar die ontwikkeling van 'n goed geïntegreerde gemeenskapslewe in die reeds gevestigde swart stadswoongebiede in gebreke gebly het, is hierdie probleem nog veel groter in die plakkersgebiede.

As daar na hierdie toedrag van sake gekyk word (en na ander instellings: die stadsbesture, werkverskaffing en die informele ekonomie, wet en orde) in die informele woongebiede wat dikwels oornag ontwikkel, dan kom die nuwe SuidAfrika voor die grootste uitdagings van hierdie eeu te staan.

\section{Die sosiale wetenskappe in die nuwe Suid-Afrika}

Om die uitdagings van die nuwe Suid-Afrika te kan hanteer, is dit noodsaaklik dat bepaalde fasiliteite en dienste verskaf sal moet word. Van die belangrikste fasiliteite wat verskaf en dienste wat ontwikkel moet word en waarvoor geld gevind en begroot moet word is die volgende:

* Die basiese infrastruktuur soos behuising (waar onder andere die gesinstruktuur en -grootte in aanmerking geneem moet word) water, riolering, strate, vervoer en gemeenskapsfasiliteite.

* Ekonomiese ontwikkeling waardeur mense arbeidsplekke verkry vir die generering van 'n inkomste, om sodoende op die lang duur die infrastruktuur te kan bekostig.

* Dit moet egter onthou word dat 'n aantal persone wat saam in 'n geografiese area woon en 'n basiese infrastruktuur het, nog nie noodwendig 'n gemeenskap vorm nie, en dit is noodsaaklik dat 'n gemeenskap, afgesien van ekonomiese strukture, verdere sosiale strukture moet ontwikkel waardeur in belangrike behoeftes van die mens voorsien kan word. Van die belangrikste sosiale strukture wat hier moet kan ontwikkel is 'n gesonde gesinslewe, kerke en 'n gemeentelike lewe, opvoedkundige instellings soos crèches, kleuterskole, laer- en hoërskole wat die nodige versorging en voorbereiding vir die lewe verseker, welsynsdienste, gesondheidsdienste, ontspanningsdienste, sekuriteit, maatskaplike beheerstrukture en die nodige leierskap en politieke strukture

Uit hierdie strukture moet daar eventueel 'n gevoel van samehorigheid, ' $n$ trots in die gemeenskap en 'n betrokkenheid in die gemeenskap ontwikkel. Die nuwe gemeenskappe moet daaraan werk om weer werklik in geïntegreerde en gebalanseerde gemeenskappe te ontwikkel, waar die lede van die gemeenskap self die verantwoordelikheid vir die ontwikkeling en groei van hul gemeenskappe neem.

Hier wag dus vir die sosiaal-wetenskaplike in die nuwe Suid-Afrika 'n reuse taak aan herstrukturering en heropbou. In hierdie taak gaan die tegnologie 'n belangrike rol speel en sal die opleiding in tegnologie en tegniese beroepe met die oog 
op ontwikkeling en werkskepping vanselfsprekend 'n belangrike rol speel. Waar die probleme ten opsigte van gemeenskapsbou egter meer as dié van net tegnologiese ontwikkeling en werkskepping is - waar dit deur en deur sosiale probleme is - is dit nie moontlik om ' $n$ laissez faire-beleid te volg met die idee dat alles op die ou end vanself sal regkom nie. Dit word dringend noodsaaklik dat daar na weë gesoek moet word on hierdie probleme op die mees doeltreffende wyse te hanteer en te voorkom, veral as die publiek daarin geïnteresseerd is om die gesofistikeerde industriële ekonomie en lewenskwaliteit waaraan hulle gewoond is, te behou. Die instandhouding van hoogs ontwikkelde samelewingstrukture eis effektiewe funksionering van die individuele lede - iets wat nie moontlik is onder toestande van grootskaalse ontwrigting en disorganisasie nie. Dit is op hierdie punt dat die taak van die sosiaal-wetenskaplike weer eens van die uiterste belang word.

In die loop van die geskiedenis is getoon dat die sosiale wetenskappe toenemend van belang word waar samelewingsproblematiek toeneem en samelewings meer ingewikkeld word. In die hedendaagse samelewing het die sosiale wetenskappe reeds op grond van die ondersteunende professies en deur die toepassing van sosiaal-wetenskaplike kennis en konsultasie getoon dat dit 'n belangrike rol in die suksesvolle funksionering van die individu en van 'n verskeidenheid organisasies gespeel het. Waar die RSA in die toekomstige Suid-Afrika voor nog meer omvattende en eskalerende sosiale probleme te staan gaan kom, sal die sosiale wetenskappe van nog groter belang as in die huidige tydsfase word.

In die eerste instansie moet die sosiale wetenskappe belangrike navorsingsinsette lewer waardeur die basiese data met die oog op beplanning verskaf word, en moet daar ook leiding gegee word vir die wyse van optrede vir die aanvaarding van die beplanning. Hier sal die individuele wetenskappe soos sosiologie, bedryfsosiologie, sielkunde, bedryfsielkunde, antropologie, politieke wetenskap, nasionale strategie, kommunikasieleer, ensovoorts, steeds belangrike insette lewer. Daar sal egter waarskynlik toenemend beweeg word in die rigting van interdissiplinêre navorsing waar die multi-dimensionele aard van bepaalde probleemareas erken word en daar vanuit 'n verskeidenheid dissiplines die nodige insette verskaf word, met die oog op die mees doeltreffende hantering van die probleem. In die tweede instansie sal daar in die hantering van hierdie probleme ook toenemend van interdissiplinêre spanwerk gebruik gemaak moet word om sodoende die probleme vanuit al die dimensies te ontleed.

Derdens moet die sosiale wetenskappe hulle doelbewus daarop toespits om, met die oog op die hantering van sosiale probleme, die data deur hul ingesamel van toepassing te maak. Die sosiaal-wetenskaplikes sal dus 'n heroriëntasie moet ondergaan deur 'n doelbewuste beroepsgerigte en professionele oriëntasie te ontwikkel. Daar moet dus 'n toename in sosiaal-wetenskaplike beroepe wees wat 
veral op gemeenskapsontwikkeling - landelik sowel as stedelik - en die ontwikkeling van sosiale dienste toegespits is.

Laastens kan daarop gewys word dat, on navorsing van hoogstaande gehalte te lewer en sosiaal-wetenskaplike beroepsoriëntasie en die toepassing van sosiaalwetenskaplike kennis te ontwikkel, dit belangrik is dat die sosiale wetenskaplike sy regmatige plek in opleiding op tersiêre vlak moet inneem. Gedurende die laaste aantal jare is daar so dikwels, wanneer die tersiêre onderwys in die kollig gekom het, beklemtoon dat technikons en universiteite hul toenemend moet toespits op spesifieke beroepsopleiding en veral op tegniese opleiding, weens die feit dat tegnici vir die ekonomiese en industriële ontwikkeling van die samelewing noodsaaklik is. Dit is wel belangrik dat hierdie opleiding plaasvind, maar in samehang hiermee moet dit uitdruklik gestel word dat hierdie opleiding nie ten koste van opleiding in die basiese sosiale wetenskappe mag plaasvind nie. Indien die opleiding van die sosiaal-wetenskaplikes agterweë bly, sal dit 'n uiters kortsigtige beleid wees - een wat in dekades nie herstel sal kan word nie. Al waartoe dit sal lei is dat daar 'n toenemende onvermoë sal ontwikkel om die sosiale probleme te kan hanteer - probleme wat op grond van die industrieel-ekonomiese ontwikkeling, die snelle verstedeliking, voortdurende verandering in Suid-Afrika, en ook weens sosiaal-historiese en politieke omstandighede, 'n eiesoortige karakter sal aanneem.

\section{Bibliografie}

BECKER, H. \& Barnes, H.E. 1961. Social Thought from Lore to Science. New York : Dover Publications

BOUWER, A. 1991. Die swart vrou se ervaring van haar man se steun vir haar universiteitstudie. Johannesburg: RAU. (MA-verhandeling.)

COLLINS, D.P. 1981. Sociological Theory: Classical Founders and Contemporary Perspectives. New York: John Wiley \& Sons

DU PLESSIS, A, DU PISANE, T. \& PLEKKER, S. 1989. Education and Manpower Development. Bloemfontein : Research Institute for Education Planning.

EVERATT, D. \& S. 1992. Back Youth in Crisis Facing the Future. Johannesburg : Ravan Press.

GILIOMEE, H. \& SCHLEMMER, L. 1985. Up Against the Fences: Poverty, Passes and Priviledge in South Africa. Johannesburg : David Phillips

GROSSKOPF, J.F.W. 1932. Plattelandsverarming en plaasverlating. Stellenbosch : Pro Ecclesia-drukkery

LAZARSFELD, P.F., SEWELL, W.H. \& WILENSKY, H.L. 1967. The Uses of Sociology New York: Basic Books

MACRAE, D. 1976. The Social Function of Social Science. New Haven: Yale Univ. Press.

OGBURN, Willaim F. 1957. Cultural Lag as Theory. Sociology and Social Research, XLI.

ROSSIDES, D.W. 1978. The History and Nature of Sociological Theory. Boston Houghton Mifflin

SENEKAL, A. \& JOUBERT, HJ. 1988. Chemiese afhanklikheid. Die Maatskaplikewerk Navorser-praktisyn. 1:15-19. 
SMELSER, Neil J. 1959. Social Change in the Industrial Revolution. London : Routledge \& Kegan Paul.

SMITH, P. \& BOOYSEN, J.J. 1981. Swart verstedeliking: Proses, patroon en strategie. Kaapstad : Tafelberg Uitgewers.

STEYN, Anna F. 1979. Interdissiplinêre navorsing: Die aard en problematiek daarvan aan universiteite. Johannesburg: RAU. A115.

STEYN, Anna F. 1991. Die uitdaging van verandering: Sosiale realiteite Verslag van die verrigtinge van die Konferensie 17-19 September 1971 in Port Elizabeth. Instituut van munisipale tesouriers en rekenmeesters.

STEYN, Anna F. 1992. Stedelike gesinstrukture in die RSA. Pretoria : RGN.

STEYN, Anna F., VAN WYK, Deon \& LE ROUX, Tessa. 1989. Die gesin gister en vandag. Kaapstad : Academica

SUNTER, C. 1987. Die wêreld en Suid-Afrika in die jare negentig. Kaapstad : Human en Rousseau.

TIMASHEFF, N.S. 1967. Sociological Theory: Its Nature and Growth. New York : Random House.

Bylae volg (kyk p. 248-252). 
Bylae A. Persentasie meisies na elke volgende

\begin{tabular}{|c|c|c|c|c|c|}
\hline Jaar & Sub A \& B & St. 1 & St. 2 & St. 3 & St. 4 \\
\hline 1955 & 228739 & & & & \\
\hline 1956 & 250976 & 83729 & & & \\
\hline 1957 & 283126 & 98117 & 90,9 & & \\
\hline 1958 & 293044 & 08641 & 85,3 & 74,5 & \\
\hline 1959 & 302078 & 110511 & 84,40 & 67,7 & 57,2 \\
\hline 1960 & 322778 & 117373 & 86,39 & 66,71 & 5,3 \\
\hline 1961 & 340824 & 123089 & 84,53 & 67,88 & 51,42 \\
\hline 1962 & 354867 & 130474 & 82,48 & 66,27 & 52,53 \\
\hline 1963 & 370587 & 135996 & 83,32 & 65,41 & 51,55 \\
\hline 1964 & 392051 & 142388 & 82,9 & 66,26 & 51,58 \\
\hline 1965 & - & - & - & - & - \\
\hline 1966 & 381585 & 135622 & - & 56,25 & 43,72 \\
\hline 1967 & 402452 & 144216 & 80,12 & - & 44,22 \\
\hline 1968 & 423048 & 155988 & 80,86 & 66,88 & - \\
\hline 1969 & 440572 & 164825 & 81,08 & 68,34 & 54,04 \\
\hline 1970 & 543164 & 209780 & 99,53 & 85,46 & 67,68 \\
\hline 1971 & 569882 & 220234 & 82,28 & 88,37 & 68,93 \\
\hline 1972 & 586244 & 232629 & 82,1 & 73,61 & 71,4 \\
\hline 1973 & 611849 & 246456 & 82,78 & 74,41 & 60,95 \\
\hline 1974 & 641827 & 253077 & 82,66 & 75,39 & 62,19 \\
\hline 1975 & 676220 & 263968 & 83,34 & 76,03 & 63,85 \\
\hline 1976 & 581741 & 235033 & 71,01 & 65,16 & 54,13 \\
\hline 1977 & 602169 & 248357 & 83,60 & 65,83 & 55,76 \\
\hline 1978 & 556872 & 224299 & - & 69,01 & 49,75 \\
\hline 1979 & - & - & - & - & 60,61 \\
\hline 1980 & - & - & - & - & - \\
\hline 1981 & - & - & - & - & - \\
\hline 1982 & - & - & - & - & - \\
\hline 1983 & - & - & - & - & - \\
\hline 1984 & - & - & - & - & - \\
\hline 1985 & - & - & - & - & - \\
\hline
\end{tabular}


Anna F. Steyn

standerd in die daaropvolgende jaar*

$\begin{array}{lllllll}\text { St. } 5 & \text { St. } 6 & \text { Vorm } 1 & \text { Vorm } 2 & \text { Vorm } 3 & \text { Vorm } 4 & \text { Vorm } 5 \\ & & \text { St. } 6 & \text { St. } 7 & \text { St. } 8 & \text { St. } 9 & \text { St. } 10\end{array}$

$\begin{array}{lllllll} & 41,4 & & & & \\ 42,54 & 38,8 & 13,3 & 44,7 & & & \\ 42,45 & 38,28 & 12,5 & 42 & & & \\ - & 40,61 & 13,26 & 40,71 & 6,9 & & \\ 35,29 & - & - & - & - & & \\ 35,94 & 33,82 & 13,11 & 9,14 & 5,51 & 3,16 & 0,46 \\ 37,58 & 34,5 & 13,79 & 9,84 & 6,42 & 0,88 & 1,87 \\ - & 35,46 & 14,91 & 10,88 & 6,62 & 0,91 & 0,51 \\ 57,28 & 38,32 & 13,8 & 11,75 & 7,7 & 0,95 & 0,56 \\ 58,99 & - & 19,04 & 15,01 & 10,95 & 1,67 & 0,74 \\ 59,88 & 60,04 & - & 16,31 & 11,7 & 2,13 & 1,12 \\ 63,14 & 61,36 & 25,52 & - & 11,92 & 2,67 & 1,27 \\ 53,56 & 63,57 & 26,47 & 22,33 & - & 2,96 & 1,55 \\ 58,83 & 66,69 & 28,37 & 23,89 & 16,37 & - & 1,73 \\ 57,29 & 35,98 & 50,47 & 32,62 & 18,66 & 5,35 & - \\ 51,95 & - & 26,99 & 31,3 & 16,79 & 5,46 & 2,43 \\ 46,25 & - & 48,17 & 18,9 & 22,83 & 6,48 & 3,06 \\ 50,44 & - & 38,82 & 31,39 & 11,63 & 6,19 & 2,75 \\ 58,21 & - & 37,71 & 31,74 & 28,9 & 4,83 & 3,9 \\ - & - & 37,52 & 31,78 & 29,06 & 13,78 & 3,12 \\ - & - & 46,29 & 31,86 & 29,05 & 15,05 & 8,73 \\ - & - & - & 36,11 & 26,34 & 16,82 & 9,75 \\ - & - & - & - & 36,73 & 14,82 & 12,62 \\ - & - & - & - & - & 19,53 & 13,09 \\ - & - & - & - & - & - & 14,54\end{array}$

* Uit Bouwer (1991:67)

Koers 58(2) 1993:231-252 
Bylae B. Persentasie seuns na elke volgende

$\begin{array}{llllll}\text { Jaar } & \text { Sub A \& B } & \text { St. } 1 & \text { St. } 2 & \text { St. } 3 & \text { St. } 4\end{array}$

\begin{tabular}{|c|c|c|c|c|c|}
\hline 1955 & 237788 & & & & \\
\hline 1956 & 267036 & 82208 & & & \\
\hline 1957 & 303856 & 98320 & 86,9 & & \\
\hline 1958 & 316218 & 109524 & 81,5 & 68,14 & \\
\hline 1959 & 324359 & 114010 & 80,04 & 61,36 & 50,35 \\
\hline 1960 & 344713 & 121264 & 82,10 & 60,98 & 46,49 \\
\hline 1961 & 363073 & 126271 & 80,5 & 60,95 & 45,72 \\
\hline 1962 & 380296 & 132296 & 78,44 & 60,54 & 45,93 \\
\hline 1963 & 397576 & 139666 & 79,47 & 60,26 & 45,27 \\
\hline 1964 & 424490 & 148259 & 79,67 & 60,77 & 45,38 \\
\hline 1965 & - & - & - & - & - \\
\hline 1966 & 410087 & 139553 & - & 52,11 & 39,51 \\
\hline 1967 & 432371 & 150160 & 77,12 & - & 39,71 \\
\hline 1968 & 455772 & 162444 & 76,94 & 63,28 & - \\
\hline 1969 & 475450 & 171066 & 77,04 & 64,47 & 49,29 \\
\hline 1970 & 587978 & 219770 & 93,62 & 78,68 & 59,5 \\
\hline 1971 & 617659 & 231450 & 77,36 & 80,31 & 60,08 \\
\hline 1972 & 638564 & 243219 & 77,14 & 66,80 & 61,52 \\
\hline 1973 & 668018 & 256940 & 78,31 & 67,72 & 52,15 \\
\hline 1974 & 696281 & 266470 & 78,22 & 69,04 & 53,13 \\
\hline 1975 & 730366 & 276058 & 78,17 & 69,49 & 54,24 \\
\hline 1976 & 627892 & 245229 & 67,11 & 60,59 & 47,89 \\
\hline 1977 & 648876 & 258278 & 78,96 & 61,03 & 49,24 \\
\hline 1978 & 596233 & 237107 & - & 64,46 & 44,6 \\
\hline 1979 & 622594 & 249975 & - & - & 54,16 \\
\hline 1980 & - & - & - & - & 51,04 \\
\hline 1981 & - & - & - & - & - \\
\hline 1982 & - & - & - & - & - \\
\hline 1983 & - & - & - & - & - \\
\hline 1984 & - & - & - & - & - \\
\hline 1985 & - & - & - & - & - \\
\hline
\end{tabular}


standerd in die daaropvolgende jaar*

$\begin{array}{lllllll}\text { St. } 5 & \text { St. } 6 & \text { Vorm } 1 & \text { Vorm } 2 & \text { Vorm } 3 & \text { Vorm } 4 & \text { Vorm } 5 \\ & & \text { St. } 6 & \text { St. } 7 & \text { St. } 8 & \text { St. } 9 & \text { St. } 10\end{array}$

\begin{tabular}{|c|c|c|c|c|c|c|}
\hline 39,95 & & & & & & \\
\hline 36,62 & 34,87 & & & & & \\
\hline 36,27 & 32,74 & 12,29 & & & & \\
\hline 36,69 & 32,73 & 11,32 & 9,05 & & & \\
\hline 36,31 & 33,97 & 12,35 & 9,17 & 7,24 & & \\
\hline - & - & - & - & - & - & \\
\hline 31,29 & 28,36 & 10,72 & 8,31 & 5,74 & 2,25 & 1,21 \\
\hline 32,12 & 29 & 10,83 & 8,86 & 6,44 & 2,08 & 1,36 \\
\hline 32,91 & 30,02 & 12,22 & 9,33 & 6,71 & 2,21 & 1,35 \\
\hline - & 31,98 & 11,7 & 10,05 & 7,46 & 2,23 & 1,47 \\
\hline 49,36 & - & 15,1 & 12,01 & 9,35 & 3,26 & 1,71 \\
\hline 50,11 & 47,97 & - & 3,01 & 9,95 & 3,82 & 2,13 \\
\hline 50,91 & 48,60 & 20,87 & - & 10,19 & 4,49 & 2,39 \\
\hline 52,91 & 50,66 & 21,66 & 18,5 & - & 4,81 & 2,60 \\
\hline 44,75 & 52,9 & 23,46 & 19,30 & 14,61 & - & 2,88 \\
\hline 44,27 & 15,09 & 38,62 & 24,86 & 15,89 & 7,89 & 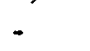 \\
\hline 49,36 & - & 21,8 & 25,99 & 15,04 & 7,41 & 4,07 \\
\hline 45,81 & - & 37,64 & 15,67 & 19,91 & 7,81 & 4,55 \\
\hline 41,21 & - & 32,26 & 25,19 & 10,56 & 7,33 & 3,63 \\
\hline 44,9 & - & 31,67 & 25,36 & 23,62 & 5,33 & 5,18 \\
\hline- & 31,43 & 25,36 & 22,45 & 12,36 & 3,65 & \\
\hline - & - & 37,37 & 25,72 & 21,95 & 12,63 & 8,43 \\
\hline - & - & - & 28,95 & 21,2 & 13,46 & 8,96 \\
\hline - & - & - & - & 28,81 & 12,47 & 10,66 \\
\hline - & - & - & - & - & 16,62 & 11,23 \\
\hline - & - & - & - & - & - & 12,49 \\
\hline
\end{tabular}

* Uit Bouwer (1991:66) 
Bylae C

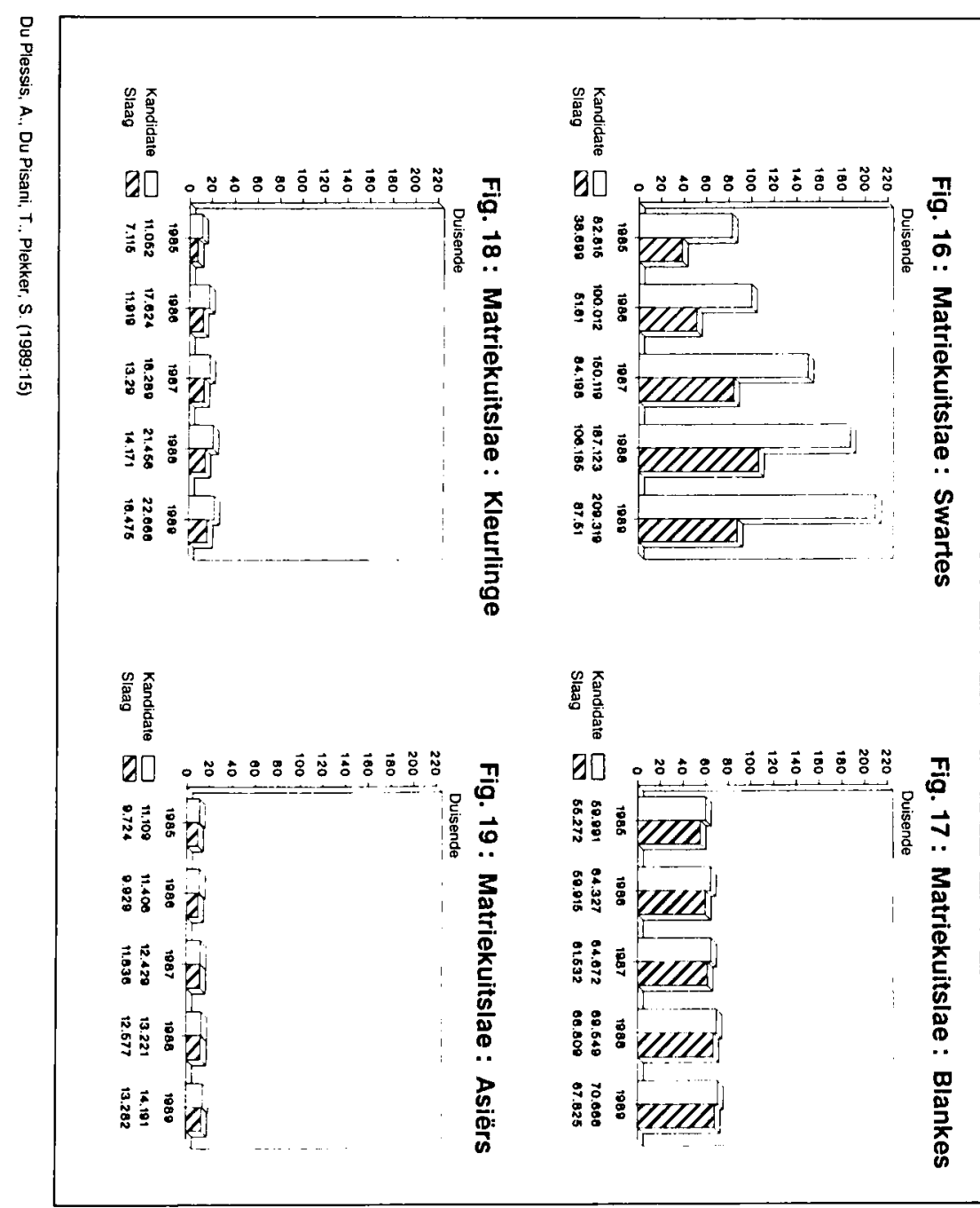

